JURNAL PENDIDIKAN, p-ISSN 2715-095X, e-ISSN 2686-5041

Volume 30, No.1, Maret 2021 (67-72)

Online: http://journal.univetbantara.ac.id/index.php/jp

\title{
Implementasi Office 365 Sebagai Pembelajaran Jarak Jauh Masa Pandemi COVID 19 di SMK Muhammadiyah Sukoharjo
}

\author{
Sawitri dan Kanya Icchanti
}

Program Studi Pendidikan Bahasa dan Sastra Jawa, Fakultas Keguruan dan Ilmu Pendidikan, Universitas Veteran Bangun Nusantara Sukoharjo

Jl. Lenjend. Sudjono Humardhani No.1 Sukoharjo - Jawa Tengah, e-mail: kanyaichaa18@gmail.com

\begin{abstract}
Abstrak: Suatu bangsa akan dikatakan berkualitas apabila generasi muda sebagai penerus bangsa nya juga berkualitas dengan kata lain generasi mudanya unggul dalam pendidikan secara akademik maupun non-akademik. Pendidikan merupakan investasi jangka panjang yang sangat berharga dan bernilai luhur terutama bagi generasi muda yang akan menentukan maju atau mundurnya suatu bangsa.Pendidikan merupakan kunci pembangunan sumber daya manusia. Pekerjaan rumah kita dalam mewujudkan kualitas pendidikan memang masih banyak. Apabila terjadi masa pagebluk seperti pandemi COVID 19. Masa pandemi seperti sekarang ini sekolah sulit memberikan pembelajaran seperti biasanya, yaitu tatap muka. Penelitian ini bertujuan untuk mengetahui 1) sistem pembelajaran jarak jauh yang diterapkan, 2) dampak dari sistem pembelajaran jauh terhadap prestasi siswa, 3) kendala dalam penerapan sistem pembelajaran jarak jauh. Adapun metode penelitian yang peneliti pakai adalah jenis penelitian deskriptif pendekatan kualitatif. Hasil dari penelitian ini adalah penerapan office 365 memang efektif sebagai pembelajaran jarak jauh masa pandemi COVID 19 namun juga memiliki dampak buruk bagi peserta didik salah satu nya adalah tingkat minat belajar peserta didik yang menurun.
\end{abstract}

Kata-kata kunci: Implementasi, Pendidikan jarak jauh, Covid 19

\section{Implementation Of Office 365 As Distance Learning During The COVID 19 Pandemic At SMK Muhammadiyah Sukoharjo}

\section{Sawitri and Kanya Icchanti}

\author{
Javanese Literature And Language Education Study Program, Faculty of Teacher Training and \\ Education, Bangun Nusantara Sukoharjo Veteran University \\ Jl. Lenjend. Sudjono Humardhani No. 1 Sukoharjo - Central Java, e-mail: kanyaichaa18@gmail.com
}

\begin{abstract}
A nation will be said to be of quality if the young generation as the successor of the nation is also qualified, in other words the young generations excels in education both academically and non-academically. Education is the key to human resource development. Our homework in realiing the national education training is still a lot. If there is a mid-week period such as the COVID 19 pandemic. Research $i$ aims to 1) the applied distance learning system, 2) the impact of the distance learning system on student achievement, 3) the obstacles in the application of the distance learning system. The research method that the researcher uses is a descriptive research company with a qualitative approach. The results and research ae that the application of office 365 is efective as distance learning during the COVID 19 pandemic, but it also has a bad impact on students, one of which is the decreasing levl of student interest in learning.
\end{abstract}

Keyword: Implementation, Distance aducation, Covid-19 


\section{Pendahuluan}

Suatu bangsa akan dikatakan berkualitas apabila generasi muda sebagai penerus bangsa nya juga berkualitas dengan kata lain generasi mudanya unggul dalam pendidikannya secara akademik maupun non-akademik. Mencetak generasi muda yang unggul dan berkualitas harus terdapat pula pendidikan yang berkualitas. Pendidikan merupakan investasi jangka panjang yang sangat berharga dan bernilai luhur terutama bagi generasi muda yang akan menentukan maju atau mundurnya suatu bangsa. Pendidikan merupakan kunci pembangunan sumber daya manusia. Pekerjaan rumah kita dalam mewujudkan kualitas pendidikan memang masih banyak. Apalagi di masa pandemi seperti sekarang ini, memiliki beberapa persoalan genting yang harus segera diselesaikan. Ini menyangkut keberlangsungan dan kualitas pendidikan peserta didik serta kesejahteraan peserta didik maupun tenaga pengajar seperti guru dan dosen. Sesulit apapun, kita harus terus memperjuangkan dan mengawal proses reformasi pendidikan sebagai kunci kejayaan NKRI. Menurut (Ardian dkk, 2020: 67) saat ini dunia pendidikan menghadapi tantangan dalam kegiatan belajar mengajar yaitu pandemi COVID-19. Pandemi COVID 19 ini melanda beberapa negara di dunia. Sehingga dari berbagai aspek mengalami kendal COVID 19 ini melanda beberapa negara di dunia. Sehingga dari berbagai aspek mengalami kendala terutamaa terutama pendidikan. Untuk menghindari penyebaran virus corona ini, pemerintah melarang adanya kerumunan, keramaian serta perkumpulan orang. Hal ini sesuai dengan surat edaran Mendikbud No.4 tahun 2020 tentang Pelaksanaan Kebijakan Pendidikan dalam Masa Darurat Penyebaran COVID 19. Dalam surat edaran tersebut berisikan bahwasanya pembelajaran dilakukan di rumah atau pembelajaran daring.

Menurut (Timbul Pardede, 2011: 1) seiring dengan perkembangan teknologi dan informasi yang sangat pesat, pembelajaran daring dalam dunia pendidikan terus berkembang. Pemanfaatan internet dalam bidang pendidikan digunakan sebagai salah satu alternatif kegiatan pembelajaran. Kegiatan proses belajar mengajar terus secara menyebar diarahkan kearah yang lebih fleksibel terhadap waktu dan tempat. Menurut (Astuti dkk, 2020: 2) permasalahan baru pun muncul dari solusi pembelajaran jarak jauh tersebut yaitu warga sekolah khususnya guru sebagai pemberi bahan ajar kepada siswa sebagian besar belum mahir dalam pemanfaatan teknologi sebagai media pembelajaran. Kompetensi dalam guru dalam menggunakan teknologi akan mempengaruhi kualitas program belajar mengajar. Di SMK Muhammadiyah Sukoharjo ini implementasi pendidikan jarak jauh menggunakan office 365 mendapatkan respon positif dari peserta didik maupun guru yang mengajar. Penelitian ini bertujuan untuk mengetahui implementasi office 365 sebagai pendidikan jarak jauh masa pandemi di SMK Muhammadiyah Sukoharjo. Selain itu penelitian ini bertujuan untuk mengetahui tanggapan dari guru dan peserta didik SMK Muhammadiyah Sukoharjo dalam hal media pembelajaran jarak jauh office 365 di masa pandemi COVID 19 ini.

\section{Metode Penelitian}

Penelitian ini mengunakan metode penelitian kualitatif. Menurut (Sugiyono, 2009: 15) penelitian kualitatif adalah suatu metode penelitian yang berlandaskan pada filsafat postpositivisme, digunakan untuk meneliti pada kondisi objek yang alamiah dimana peneliti adalah sebagai instrumen kunci, pengambilan sampel sumber data bersifat kualitatif, dan hasil penelitian kualitatif lebih menekankan makna daripada generalisasi. Penelitian kualitatif bertumpu pada latar belakang alamiah secara holistik, memposisikan manusia sebagai alat penelitian, melakukan analisis data secara induktif, lebih mementingkan proses daripada hasil serta hasil penelitian yang dilakukan disepakati oleh peneliti dan subjek 
penelitian. Instrumen penelitian ini adalah penulis sendiri penulis melakukan wawancara yang berisi pertanyaan-pertanyaan yang disesuaikan dengan pokok permasalahan dalam penelitian ini. Pokok permasalahan ini dapat berkembang sehingga penulis menemukan informasi lain yang berhubungan dengan pokok permasalahan selama wawancara berlangsung. Dalam penelitian kualitatif tidak menggunakan istilah populasi tetapi menurut (Sugiyono 2007: 49) dinamakan social situation atau situasi sosial yang terdiri atas tiga elemen yaitu tempat, pelaku, dan aktivitas yang berinteraksi secara sinergis. Dalam penelitian ini reponden yang berkaitan sebanyak 4 orang dari SMK Muhammadiyah Sukoharjo terdiri dari 3 siswa dan 1 guru.

Tabel 1. Responden

\begin{tabular}{|ccc|}
\hline Inisial & Jenis & Jabatan \\
\hline Responden & Laki-laki & Peserta didik \\
\hline Responden & Laki-laki & Peserta didik \\
\hline Responden & Laki-laki & Peserta didik \\
\hline Responden & Laki-laki & Guru \\
\hline
\end{tabular}

Wawancara dilakukan terstruktur dengan pertanyaan yang disusun dan dikaitkan serta dikembangkan dengan literature terkait. Sampel diambil menggunakan metode purposive sample. Menurut (Fuad Zainul, dkk 2019: 82) Metode ini merupakan metode pengambilan sampel yang banyak digunakan pada penelitian yang kondisi status suatuwilayah, kondisi geografis, keanekaragaman hayati pada suatu wilayah apabila kondisinya cenderung heterogen. Kondisi tersebut menyebabkan peneliti mengalami kesulitan untuk mendapatkan sampel jika tidak ada unsur kesengajaan dalam pengambilan sampel tersebut. Menurut (Sugiyono 2011: 84) mengatakan bahwa purposive sample adalah teknik untuk menentukan sampel dengan pertimbangan khusus.

Menurut (Hermawan, 2008: 17) penelitian eksploratif adalah suatu jenis penelitian sosial yang tujuannya untuk memberikan sedikit definisi mengenai konsep atau pola yang digunakan dalam penelitian. Untuk mendapatkan temuan melalui analisis, peneliti menyiapkan beberapa pertanyaan guna untuk mengetahui beberapa informasi dari responden dengan izin peneliti dan persetujuan responden maupun pihak-pihak terkait Berikut pertanyaan yang peneliti ajukan: (1). Sejak kapan pembelajaran jarak jauh dilaksanakan? (2). Apakah media office 365 efektif untuk pembelajaran jarak jauh ini? (3). Apakah peserta didik dapat memahami materi yang diberikan guru melalui media office 365? (4). Apakah interaksi antara guru dan peserta didik terjalin dengan baik selama pembelajaran jarak jauh ini? (5). Apa dampak baik maupun buruk dari pembelajaran jarak jauh menggunakan media office 365 ?

Mile dan Huberman seperti yang dikutip oleh (Agus Salim, 2006: 20-24), ada 3 cara pengolahan data kualitatif, yakni reduksi data (data reduction), penyajian data (data display), serta penarikan kesimpulan (conclusion drawing and verification) merupakan cara yang luwes dan tidak terikat batasan kronologis. Reduksi data, tahap ini peneliti melakukan pemilihan, dan pemusatan perhatian untuk penyedehanaan, abstraksi, dan transformasi data kasar yang diperoleh. Penyajian data, peneliti mengembangkan sebuah deskripsi informasi tersusun untuk menarik kesimpulan dan pengambilan tindakan dan dalam bentuk naratif. Penarikan kesimpulan, dengan melakukan verifikasi dengan mencari makna setiap gejala yang diperolehnya dari lapangan, mencatat keteraturan dan konfigurasi yang mungkin ada, alur kausalitas dari fenomena juga proposisi. Menurut (Kirk dan Miller, 1986: 41-42) keabsahan data penelitian dapat dilihat dari kemampuan menilai data dari aspek validitas 
dan reliabilitas data penelitian. Untuk menguji validitas penelitian dapat dilakukan dengan metode triangulasi dimana peneliti menemukan kesepahaman dengan subjek penelitian. Reliabilitas dapat dilakukan dengan melakukan atau menerapkan prosedur fielnote atau catatan lapangan dengan prosedur yang akan ditetapkan.

\section{Hasil Penelitian}

Peneliti menggunakan teknik wawancara kepada 4 responden didapatkan hasil untuk menjawa pertanyaan dari Bab 1 mengenai implementasi pembelajaran jarak jauh masa pandemi di SMK Muhammadiyah Sukoharjo. Berikut hasil wawancara dari ke-4 responden.

Responden 1: (1). Sejak kapan pembelajaran jarak jauh dilaksanakan? Jawaban responden sebagai peserta didik: kalau saya sejak Maret tanggal 15 tahun 2020. (2). Apakah media office 365 efektif untuk pembelajaran jarak jauh? Jawaban responden: sangat efektif. (3). Apakah peserta didik dapat memahami materi yang diberikan guru melalui media office 365? Jawaban responden: ya, bisa memahami. (4). Apakah interaksi antara guru dan peserta didik terjalin baik selama pembelajaran jarak jauh ini? Jawaban responden: menurut saya masih kurang. (5). Apa saja dampak baik maupuun buruk dari pembelajjaran jarak jauh menggunakan office 365? Jawaban responden: buruknya bagi peserta didik yang sulit untuk mengerti materi pelajarannya, baiknya bagi peserta didik bisa lebih mandiri dan pelajaran dapat dipelajari kapan saja dimana saja.

Responden 2: (1). Sejak kapan pembelajaran jarak jauh ini dilaksanakan? Jawaban responden sebagai peserta didik: sekitar bulan maret kalau tidak salah. (2). Apakah media office 365 efektif untuk pembelajaran jarak jauh ini? Jawaban responden: saya rasa kurang efektif. (3). Apakah peserta didik dapat memahami materi yang diberikan guru melalui media office 365 ? Jawaban responden: bisa, tapi tidak semua dapat dipahami. (4). Apakah interaksi antara guru dan peserta didik terjalin baik selama pembelajaran jarak jauh? Jawaban responden: ya, tetap terjalin baik. (5). Apa saja dampak baik maupun buruk dari pembelajaran jarak jauh menggunakan office 365? Jawaban responden: baiknya, lebih banyak waktu belajar, menghemat biaya pengeluaran sekolah seperti bensin, buruknya tidak dapat berkumpul dengan teman sekelas alias kangen.

Responden 3: (1). Sejak kapan pembelajaran jarak jauh ini dilaksanakan? Jawaban responden sebagai peserta didik: sejak pandemi COVID 19. (2). Apakah media office 365 efektif untuk pembelajaran jarak jauh ini? Jawaban responden: sangat bermanfaat bagi siswa dan dunia pendidikan, tapi terkadang kita kurang percaya diri pada saat video conference yang dilakukan oleh beberapa guru. (3). Apakah peserta didik dapat memahami materi yang diberikan guru melalui media office 365? Jawaban reponden: sangat mudah memahami konsep materi. (4). Apakah interaksi antara guru dan peserta didik terjalin baik selama pembelajaran jarak jauh? Jawaban responden: bisa dikatakan tidak. (5). Apa saja dampak baik maupun buruk dari pembelajaran jarak jauh menggunakan office 365 ? Jawaban respoden: buruknya, menjadi malas untuk belajar, kurang bersosialisasi, keterbatasan kuota internet, baiknya, banyak memiliki waktu bersama keluarga, metode belajar ada banyak varian, sebagian teman saya ada yang senang juga karena waktu pengumpulan tugas yang cukup lama.

Responden 4: (1). Sejak kapan pembelajaran jarak jauh ini dilaksanakan? Jawaban responden sebagai pengajar: sebenarnya di SMK Muhammadiyah Sukoharjo ini sudah lama 
menerapkan pendidikan berbasis internet menggunakan e-learning seperti moodle, quipper sejak tahun 2015 kalau tidak salah tetapi saat itu hanya anak TKJ,TKR, RPL saja yang lain beluum menggunakan lama-kelamaan seluruh peserta didik dan guru menggunakan office 365 untuk pembelajaran jarak jauh masa pandemi ini. (2). Apakah media office 365 efektif untuk pembelajaran jarak jauh ini? Jawaban responden: menurut saya efektif karena dalam satu aplikasi office 365 itu mencakup beberapa aplikasi yang sangat membantu guru dalam menyampaikan materi seperti Sway, Word, Power Point dan sebagainya. (3). Apakah peserta didik dapat memahami materi yang diberikan guru melalui media office 365 ? Jawaban responden: peserta didik saya rasa kurang dalam memahami materi karena terkadang tidak mengikuti jam mata pelajaran karena kendala sinyal, ada kesibukan lain, atau mungkin izin sakit. (4). Apakah interaksi antara guru dan peserta didik terjalin baik selama pembelajaran jarak jauh? Jawaban responden: alhamdulillah antara peserta didik dan guru terjalin dengan baik selama saya mengajar. (5). Apa saja dampak baik maupun buruk dari pembelajaran jarak jauh menggunakan office 365? Jawaban responden: buruknya adalah dimana guru kurang bisa mengontrol siswa dalam pembelajaran, keadaan siswa tidak bisa dideteksi apakah peserta didik sudah menguasai atau belum materi yang sudah disampaikan guru, lalu validitas daya serap peserta didik yang sulit karena minat belajar menurun, dampak baik dari pembelajaran jarak jauh ini dapat mengantisipasi penyebaran COVID 19 di masa pandemi, peserta didik dapat lebih fleksibel dalam mengikuti mata pelajaran, dapat mengakses materi kapan saja selama ada akses internet.

\section{Pembahasan}

Dari hasil wawancara diatas dapat diketahui bahwa implementasi office 365 sebagai pendidikan jarak jauh masa pandemi COVID-19 di SMK Muhammadiyah Sukoharjo ini merupakan gambaran sikap mandiri peserta didik, tanggung jawabnya pada tugas yang diberikan oleh guru, diskusi-diskusi melalui kelas secara online. Terkait tujuan penelitian ini berdasarkan hasil wawancara dengan beberapa responden yang terdiri dari 4 responden yaitu 3 peserta didik dan 1 guru yaitu 1) sistem pembelajaran jarak jauh yang diterapkan seperti yang telah diketahui bahwa SMK Muhammadiyah Sukoharjo yang sudah mengadakan pembelajaran berbasis online sejak tahun 2015 menggunakan aplikasi quipper dan moodle namun hanya beberapa kelas saja yang menerapkan seperti kelas TKR, TKJ, RPL. Namun akibat pandemi ini SMK Muhammadiyah Sukoharjo lebih mengembangkan pendidikan jarak jauh menggunakan office 365 yang lebih lengkap dan dianggap mampu dipelajari dengan mudah oleh peserta didik maupun guru. Peserta didik juga merasa lebih nyaman menggunakan office 365 karena mata pelajaran dianggap lebih mudah dikuasai oleh peserta didik. 2) dampak dari sistem pembelajaran jarak jauh, seperti yang diketahui dalam melakukan suatu pembaharuan pasti terdapat dampak baik maupun buruk yang diberikan. Dalam pendidikan jarak jauh menggunakan office 365 ini dampak buruknya bagi peserta didik dari segi keterbatasan kuota karena memang peserta didik harus memiliki kuota internet dan akses internet yang cukup untuk bisa mengikuti pendidikan jarak jauh berbasis online. Terhadap prestasi siswa SMK Muhammadiyah Sukoharjo ini, walaupun guru sudah berusaha untuk memberi pelajaran secara daring melalui office 365 namun peserta didik masih banyak yang lalai dalam pembelajaran atau bahkan tidak sedikit yang lupa mengerjakan pekerjaan rumah, secara tidak langsung sangat mempengaruhi prestasi peserta didik. Banyak prestasi peserta didik SMK Muhammadiyah Sukoharjo yang menurun. 3) kendala dalam penerapan sistem pembelajaran jarak jauh, keterbatasan minat belajar peserta didik yang menurun karena sibuk dengan pekerjaan sampingan mereka atau 
membantu orang tua, kendala lain dalam perangkat keras atau alat pembelajaran yang kurang memadai, kendala lain terdapat dalam akses internet di rumah masing-masing peserta didik yang kurang memadai. Dan kendala yang terakhir terdapat pada kuota internet yang tidak semua peserta didik mampu membeli atau terkendala dalam biaya untuk pembelian kuota akses internet.

\section{Simpulan dan Saran}

Implementasi office 365 sebagai pembelajaran jarak jauh masa pandemi COVID 19 di SMK Muhammadiyah Sukoharjo ini memiliki tujuan yaitu untuk tetap melakukan pembelajaran kepada peserta didik di masa pandemi COVID 19 ini. Penerapan pembelajaran berbasis online ini sudah lama diterapkan di SMK Muhammadiyah Sukoharjo yaitu sejak tahun 2015 namun hanya peserta didik jurusan TKJ, RPL, TKR saja yang menerapkannya namun di masa pandemi COVID 19 seluruh peserta didik menggunakan office 365 sebagai aplikasi daring selama pandemi COVID 19 ini. Penerapannya selama beberapa bulan ini memiliki dampak baik yaitu pencegahan penularan COVID 19 lebih meluas, efisiensi waktu dan biaya transportasi. Namun dampak buruknya bagi peserta didik, menurunnya minat belajar peserta didik ada beberapa faktor yang mempengaruhi salah satunya membantu pekerjaan orang tua di rumah selama orang tua mereka bekeja untuk menghidupi kebutuhan keluarga, perangkat lunak yang tidak memadai untuk pembelajaran daring, maupun akses kuota internet yang kurang baik di daerah mereka dan juga biaya kuota internet yang tidak murah dikeluarkan setiap bulannya. Untuk itu hendaknya sekolah memiliki solusi bagi peserta didik yang memiliki keluhan-keluhan dalam akses internet seperti kuota, bisa dilakukan dengan pemberian kuota internet untuk belajar per bulan kepada psesrta didik. Dapat juga dengan pomotongan SPP sebesar beberapa persen dan sebaiknya digunakan untuk kebutuhan sekolah ataupun untuk pembelian kuota internet untuk belajar peserta didik.

\section{Daftar Rujukan}

Agus Salim. (2006). Teori dan Paradigma Penelitian Sosial: Buku Sumber untuk Penelitian Kualitatif. Yogyakarta: Tiara Wacana.

Ardian dkk, (2020). Pemanfaatan Microsoft Sway dan Microsoft Form Sebagai Media Interaktif Dalam Pembelajaran Sejarah. Diambil dari: http://jurnal.unsil.ac.id/index.php/bihari/article/view/2520.

Asep H. Hermawan, dkk. (2008). Pembangunan Kurikulum dan Pembelajaran. Jakarta: Universitas Terbuka.

Astuti dkk, (2020). Pelatihan Pembelajaran Microsoft 365 Pada Guru Sekolah Dasar Negeri 02 Banjarturi Warureja Tegal. Diambil dari: https://kkn.unnes.ac.id/lapkknunnes/32004_3328162011_6_Desa\%20Bojongsana 2 0200909 140554.pdf.

Fuad, Zainul, dkk. (2019). Metode Penelitian Kualitatif. Bandung: Remaja Rosdakarya.

Kirk, J. \& Miller, M. L. (1986). Reliability and Validity in Qualitative Research. Beverly Hills: CA, Sage Publications.

Sugiyono. (2011). Metode Peneltian Kuantitatif, Kualitatif, dan R\&D. Bandung: Alfabeta. Sugiyono. (2009). Metode Penelitian Kuantitatif, Kualitatif dan R\&D. Bandung: Alfabeta.

Timbul Pardede. (2011). Pemanfaatan E-Learning Sebagai Media Pembelajaran Pada Pendidikan Tinggi Jarak Jauh. Diambil dari: http://repository.ut.ac.id/2511/fmipa201144.pdf 